\title{
Revenue Management: A Retrospective
}

The techniques of revenue management have potential application in many industries-as long as customers view the resulting policies as being fair.

BY SHERYL E. KIMES

$\mathrm{I}$ have been privileged to be at Cornell since 1988, a date which roughly marks the beginning of revenue manage1 ment in the hotel industry. Since my first article on the topic was published in $1989,{ }^{1}$ I have seen revenue management become widely accepted within the hotel industry, increase in technical sophistication, be applied to other industries, and even change its name (from yield management to revenue management). In this paper I trace the evolution of my research in revenue management, including the 11 articles that have appeared in Cornell Quarterly over this time, and discuss areas for future research.

In the late 1980 s revenue management was in the early stages of development, and the major North American hotel chains (notably, Marriott, Hilton, Holiday Inn, and Sheraton) had started what would now be considered rudimentary revenue-management systems. My 1989 paper represented an attempt to discuss revenue management in general and to explain possible implementation approaches and concerns to hotel managers. In that article I presented the necessary conditions for revenue management. These conditions (relatively fixed capacity, perishable inventory, reservations made in advance, appropriate cost structure, variable demand, and segmentable markets) have been used to assess the application of revenue management in other parts of the hotel and to other industries. The techniques discussed have increased in sophistication within the hotel industry but are srill under 


\section{EXHIBIT 1}

Typical pricing and duration positioning of selected service industries

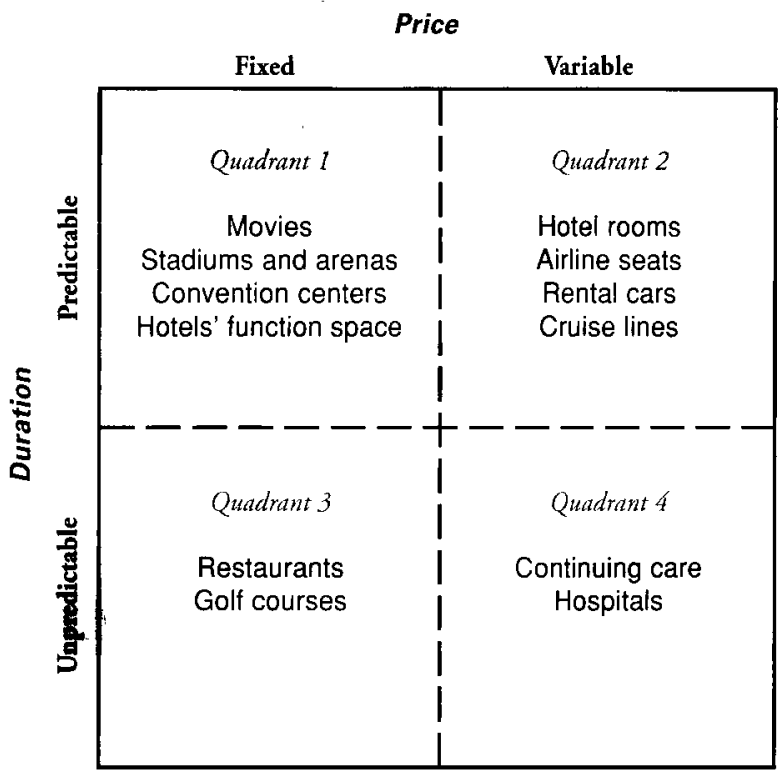

Table drawn from: S.E. Kimes and R.B. Chase, "The Strategic Levers of Yield Management," Journal of Service Research, Vol. 1, No. 2 (1998), pp. 156-166. Versions of this diagram were previously used in: Sheryl E. Kimes, Richard B. Chase, Sunmee Choi, Philip Y. Lee, and Elizabeth N. Ngonzi, "Restaurant Revenue Management: Applying Yield Management to the Restaurant Industry," Cornell Hotel and Restaurant Administration Quarterly, Vol. 39, No. 3 (June 1998), p. 39; Sheryl E. Kimes, "Revenue Management on the Links: Applying Yield Management to the Golf-course Industry," Cornell Hotel and Restaurant Administration Quarterly, Vol. 41, No. 1 (February 2000), p. 127; Lawrence R. Weatherford, Sheryl E. Kimes, and Darren A. Scott, "Forecasting for Hotel Revenue Management: Testing Aggregation Against Disaggregation," Cornell Hotel and Restaurant Administration Quarterly, Vol. 42, No. 4 (August 2001), p. 54; and, most recently, in Sheryl E. Kimes and Kelly A. McGuire, "Function-space Revenue Management: A Case Study from Singapore," Cornell Hotel and Restaurant Administration Quarterly, Vol. 42, No. 6 (December 2001), p. 34. development in restaurants, golf courses, and function space.

Revenue-management research can generally be divided into the following three streams: (1) descriptive (application of revenue management concepts to various industries), (2) pricing control (development and improved management of pricing strategies), and (3) inventory control (improved management of customer arrival and use patterns). In the following sections I discuss each of these research streams.

\section{Descriptive Revenue-management Research}

To understand and expand on this stream of research, a thorough understanding of the necessary conditions for revenue management is required. For example, in my 1989 paper I discussed the necessary conditions for revenue management, ${ }^{2}$ but the question becomes one of identifying whether and how an industry satisfies those conditions and then exploring how its practitioners might best use revenue-management concepts.

The appropriate revenue-management techniques to use depend on the industry. Although the strategic framework shown in Exhibit 1 has been presented before, ${ }^{3}$ I find it invaluable for determining the appropriate revenuemanagement tools to use for a specific industry. Revenue managers may deploy the following two strategic levers to a greater or lesser extent, depending on their industry: duration control and pricing management. Duration (or inventory) control, refers to the pacing and prediction of customer arrivals and length of customer use. Pricing management includes the development of the best set of prices for various customer segments, the determination of the rules that determine who pays what price, and the perceived fairness of the resulting prices and rules.

\section{${ }^{2}$ Ibid.}

${ }^{3}$ S. E. Kimes and R. B. Chase, "The Strategic Levers of Yield Management," Journal of Service Research, Vol. 1, No. 2 (1998), pp. 156-166; and S.E. Kimes, R.B. Chase, S. Choi, E.N. Ngonzi, and P.Y. Lee, "Restaurant Revenue Management," Cornell Hotel and Restaurant Administration Quarterly, Vol. 40, No. 3 (June 1998), pp. 40-45. 
Industries meeting the necessary conditions for revenue management can be classified on the basis of their use of these two strategic levers. Quadrant-1 industries (such as function space, movie theaters, convention centers, and sports arenas) offer only a few prices but exercise control over duration of use. Since duration is already controlled (either through the type of service sold or through required deposits), most Quadrant-1 revenue-management programs consist of pricing tools. Quadrant-2 industries (such as hotels, airlines, rental-car companies, and cruise lines) generally control duration and have many prices. Revenue-management efforts for these firms generally revolve around length-ofuse controls, enhanced use of variable pricing, and expansion of revenue-management concepts to other parts of the business (e.g., spas, restaurants, golf courses). Quadrant-3 industries (such as restaurants and golf courses) generally offer few prices and have little direct control over duration of use. Revenue-management programs in these industries can use both duration control and pricing management. Finally, Quadrant-4 industries (typically health care) offer many prices, but have little control over duration.

An understanding of the logic underlying the classification scheme is necessary for determining which revenue-management tools are most appropriate for a particular industry. For example, since customer arrival and duration is fairly certain in function-space sales (primarily because of the stringent deposit policies in effect), pricing takes precedence. In Quadrant-3 industries, such as restaurants and golf courses, in contrast, both pricing and duration control must be used because they sell an event rather than explicitly sell a particular time period.

My first dip into this last stream of research was in 1998 with a paper on restaurant revenue management. ${ }^{4}$ In that article my coauthors and I analyzed each of the necessary conditions for revenue management and presented the strategic framework that I just described to determine which revenue-management tools might be most

${ }^{4}$ Kimes et al. (1998), op.cit. appropriate for the restaurant industry. Restaurant capacity is generally not as fixed as that of the hotel industry, and the variable-cost percentage is higher, but revenue management principles are equally applicable to the restaurant industry. In a subsequent paper,5 I further explored the performance measurements for restaurant revenue management (namely, RevPASH, or revenue per available seat-hour) and presented a five-step process that restaurant operators can use for developing revenue management. Further research (described in more detail below) discussed how revenue management was applied at Coyote Loco in Ithaca, New York, ${ }^{6}$ and at Chevys FreshMex Restaurants, in suburban Phoenix.?

I performed similar studies for the golf and function space industries. ${ }^{8}$ For example, golf courses have relatively fixed capacity (although they can alter capacity by decreasing the amount of time between parties ${ }^{9}$ ), have extremely perishable inventory, have a low-variable cost percentage, have variable demand, have a large percentage of reservations made in advance, and have varying customer price sensitivity.

${ }^{5}$ S.E. Kimes, "Implementing Restaurant Revenue Management: A Five-step Approach," Cornell Hotel and Restaurant Administration Quarterly, Vol. 40, No. 3 (June 1999), pp. 16-21.

${ }^{6}$ S.E. Kimes, D.I. Barrash, and J.E. Alexander, "Developing a Restaurant Revenue-Management Strategy," Cornell Hotel and Restaurant Administration Quarterly, Vol. 34, No. 5 (October 1999), pp. 18-30.

${ }^{7}$ S.E. Kimes, "Restaurant Revenue Management: Implementation at Chevys Arrowhead," Cornell Hotel and Restaurant Administration Quarterly, forthcoming (Vol. 45, No. 1 [February 2004]).

${ }^{8}$ S.E. Kimes, "Revenue Management on the Links: Applying Yield Management to the Golf Industry," Cornell Hotel and Restaurant Administration Quarterly, Vol. 41, No. 1 (February 2000), pp. 120-127; and S.E. Kimes and K.A. McGuire, "Function Space Revenue Management: A Case Study from Singapore," Cornell Hotel and Restaurant Administration Quarterly, Vol. 42, No. 6 (December 2001), pp. 33-46.

${ }^{9}$ S.E. Kimes and L.W. Schruben, "Golf-course Revenue Management: A Study of Tee-time Intervals," Journal of Revenue and Pricing Management, Vol. 1, No. 2 (2002), pp. 111-120. 


\section{Pricing Research}

I first became interested in customers' reaction to demand-based pricing in the early 1990s. Whenever I visited the corporate offices of large hotel chains and asked how customers reacted to variable prices, I was assured that there was no problem and that customers were happy. When I visited individual properties, I heard a completely different story. Managers told me that upset guests and front-desk clerks described many unpleasant customer encounters.

I decided to study how customers reacted to demand-based pricing in horels and airlines, but first I had to find an appropriate way of framing the issue. It was obvious that I just could not ask people if they preferred to pay a higher or lower price. (I was pretty sure I knew the answer!) Luckily, one of my graduate students, Kathleen Denison, was taking a consumer-decision course from Richard Thaler, one of the seminal thinkers in behavioral economics, and told me of research on perceived fairness. ${ }^{10}$

The terms "reference transaction" and "reference price" are often used when discussing fairness. A reference transaction represents how customers think a transaction should be conducted and a reference price is the benchmark for how much customers think a service should cost. Reference prices can come from the price last paid, the price most frequently paid, what other customers paid for similar offerings, or from market prices and posted prices. For example, customers may know that they generally pay about $\$ 25$ for dinner at a particular restaurant, and so the reference price for dinner at the restaurant would be $\$ 25$.

Perceived-fairness research has shown that most customers believe that they are entitled to a reasonable price and that firms are entitled to a reasonable profit. ${ }^{11}$ Customers are likely to view the demand-based pricing associated with revenue management as unbalancing that relationship by

\footnotetext{
${ }^{10}$ D. Kahneman, J.L. Knetsch, and R.H. Thaler, "Fairness and the Assumption of Economics," Journal of Business, Vol. 59 (1986), pp. S285-S300; and R.H. Thaler, "Mental Accounting and Consumer Choice," Marketing Science, Vol. 4, No. 3 (1985), pp. 199-214.

$"$ Ibid.
}

either increasing the value to the firm without increasing the value to the customer, or by decreasing the value to the customer without a substantial enough price reduction. As a result, customers may view such transactions as unfair. For example, if a hotel increases its room rates for no apparent reason, it is increasing the firm's value without increasing the customer's, and customers may then view the transaction as unfair. Similarly, if a hotel imposes substantial restrictions on customers in exchange for only a somewhat lower room rate, customers may view the transaction as unfair.

We decided to study perceived fairness in the cruise-line industry. ${ }^{12}$ We found that customers were willing to accept reasonable restrictions on their purchase in exchange for reduced prices or for additional benefits. After this, I decided to study customer reaction to demand-based pricing in the hotel and airline industries. ${ }^{13}$ I found that customers were more accepting of airline practices than those of hotels (which was not surprising since revenue management had a longer history in the airline industry). I also found that customers viewed information on pricing options as essential and that they were willing to accept reasonable restrictions on their purchase in exchange for a reduced price.

In a follow-up study in 2001, my associates and I found that customer perception of demandbased-pricing policies was the same for both the hotel and airline industries. ${ }^{14}$ From this study we learned that reference prices and reference transactions can change over time. For example, practices originally thought of as unfair (such as hotel guests paying different prices for essentially the same room type) may attain the status of a reference transaction over time. ${ }^{15}$

\footnotetext{
${ }^{12}$ K.A. Denison, "Perceived Fairness of Yield Management in the Cruise Industry," Cornell University, MPS Monograph, 1991.

13 S.E. Kimes, "Perceived Fairness of Yield Management," Cornell Hotel and Restaurant Administration Quarterly, Vol. 29, No. 1 (February 1994), pp. 22-29.

${ }^{14}$ S.E. Kimes, "Perceived Fairness of Yield Management: An Update," Cornell Hotel and Restaurant Administration Quarterly, Vol. 43, No. 1 (February 2002), pp. 28-29.
}

${ }^{15}$ D. Kahneman, J. L. Knetsch, and R. H. Thaler, op. cit. 
Changes in the reference transaction can be readily seen in customer reaction to revenue management in other industries. Revenue management has been practiced in the airline industry for nearly 25 years and in the hotel industry for approximately 15 years, but has only recently gained attention in the restaurant and golf industries.

Whenever I talked with restaurant or golf operators about revenue management, they told me that their customers would never accept demandbased pricing. I decided to find out whether this was true. In our first study, ${ }^{16}$ we surveyed potential restaurant customers about their reaction to five different demand-based-pricing scenarios (based on variations in time of day, lunch versus dinner, day of week, coupons, and table location) and two different framing methods (discount or surcharge). We found that customers viewed time-of-day pricing, differential lunch and dinner pricing, day-of-week pricing, and the use of coupons as acceptable (in fact, more acceptable than in the hotel or airline industry), but viewed table-location pricing as slightly unfair. When the price difference was framed as a discount, it was viewed as significantly more acceptable than when it was framed as a premium, even though the two scenarios were economically equivalent. This is consistent with prospect theory, which holds that price differences framed as a customer gain (i.e., discounts) are fairer than those framed as a customer loss (i.e., premiums or surcharges), even if the situations are economically equivalent. ${ }^{17}$

We expanded this study to include customers in Singapore and Sweden and found similar results, although customers' reaction varied by country. ${ }^{18}$ The Swedish respondents were most

${ }^{16}$ S.E. Kimes and J. Wirtz, "Perceived Fairness of Demandbased Pricing for Restaurants," Cornell Hotel and Restaurant Administration Quarterly, Vol. 43, No. 1 (2002), pp. 31-38

17 D. Kahneman and A. Tversky, "Prospect Theory: An Analysis of Decision Under Risk," Econometrica, Vol. 47, No. 2 (1979), pp. 263-291; and Thaler, op.cit.

${ }^{18}$ S.E. Kimes and J. Wirtz, "When Does Revenue Management Become Acceptable?," Journal of Service Research, forthcoming (2003). accepting of demand-based pricing, followed by the American respondents, and then by the Singaporean respondents.

We conducted a similar survey for the golf industry. ${ }^{19}$ As with restaurant customers, golfers viewed most demand-based pricing practices as acceptable, but felt that constantly changing prices were unacceptable. Once again, the framing of the questions mattered. Price-

\section{Depending on the perceived fairness of a transaction, customers will accept reason- able purchasing restrictions in exchange for reduced prices.}

manipulation scenarios framed as discounts were rated as significantly more acceptable than those framed as premiums.

\section{Duration-control Research}

Duration of customer use can be controlled through either the management of the arrival process or of actual customer length of use..$^{20}$ The majority of my duration-based research has focused on the arrival-management process, although some of my more recent research has focused on duration of use. Arrival management can be divided into internal and external approaches. Internal arrival methods include forecasting, overbooking, and optimal supply mix. My research has focused on forecasting and the optimal supply mix.

\section{Forecasting}

Accurate forecasts are the linchpin of any successful revenue-management system. We used hotel data to study the accuracy of various forecasting methods and found that pickup methods (in which the expected number of future reser-

\footnotetext{
${ }^{19}$ S.E. Kimes and J. Wirtz, "Perceived Fairness of Revenue Management in the Golf Industry," Journal of Revenue and Pricing Management, Vol. 2, No. 1 (2003), pp. 332-344.

${ }^{20}$ Kimes and Chase, op.cit.
} 
vations is added to the reservations on hand) and simple exponential smoothing produced the most accurate results. ${ }^{21}$

Hotels with sophisticated revenue-management systems typically apply length-of-stay controls to a variety of rate categories. For example, they may impose a two-night minimum length of stay on a $\$ 99$ rate, but a three-night minimum stay on a $\$ 79$ rate. The use of such controls requires forecasts by rate and length of stay. We studied the effect of increased forecast disaggregation on forecast accuracy to see whether the best approach was to forecast by rate class and length of stay or to aggregate forecasts by either rate class, length of stay, or both rate class and length of stay. ${ }^{22}$ We found that increased disaggregation led to more-accurate forecasts.

In similar research, I worked with Sunmee Choi to study the effects of taking distribution channel into account in revenue management. ${ }^{23}$ Specifically, we studied whether forecasting by rate class, length of stay, and distribution channel produced more-accurate forecasts than simply forecasting by rate class and length of stay. We found that increased forecast disaggregation led to more accurate forecasts but that managing the distribution channel did not result in significantly increased profit.

I have also addressed the accuracy of group forecasts. ${ }^{24}$ The group forecast is a typical input to any hotel revenue-management program, and an inaccurate group forecast has serious implications for revenue-management performance. I obtained data from about 100 properties of a large hotel chain and analyzed the accuracy of

${ }^{21}$ L.R. Weatherford and S.E. Kimes, "Forecasting Methods for Hotel Revenue Management: An Evaluation," International Journal of Forecasting, Vol. 19, No. 3 (2003), pp. $405-419$.

${ }^{22}$ L.R. Weatherford, S.E. Kimes and D.A. Scott, "Forecasting for Hotel Revenue Management: Testing Aggregation against Disaggregation," Cornell Hotel and Restaurant Administration Quarterly, Vol. 42, No. 4 (August 2001), pp. 53-64.

${ }^{23}$ S. Choi and S.E. Kimes, "The Impact of Distribution Channels on Revenue Management," Cornell Hotel and Restaurant Administration Quarterly, Vol. 43, No. 3 (June 2002), pp. 23-31. their group forecasts. I found that on average, the forecast error at one month before arrival was 35 percent and was 15 percent on the day of arrival. The error rates varied by hotel, but still, it appears that group forecasting error is substantial.

\section{Optimal Supply Mix}

If a company does not have the optimal supply mix (the mix of tables in a restaurant or the mix of rooms in a hotel), it will never be able to achieve its revenue potential. In a pilot study conducted in a Chevys FreshMex restaurant, I found that even though over half of its customers were in parties of one or two most of its tables were tables for four! As a consequence, the restaurant's seat occupancy rarely exceeded 50 percent even when customers were waiting. ${ }^{25}$ My associates and I developed a simulation model that allowed us to enumerate all possible table mixes and to select the one that produced the highest revenue. ${ }^{26} \mathrm{By}$ selecting and installing a "near optimal" table mix, Chevys was able to increase its revenue by 5 percent. In further research, we have developed and tested heuristic methods that can be used to solve this model. ${ }^{27}$

\section{Customer Duration}

In recent years, I have started to look at customer duration. Although a few of my articles (most notably the articles on Coyote Loco and Chevys ${ }^{28}$ ) talk about ways in which restaurants have reduced duration, they are more descriptive than empirical. Meal duration can have an enormous impact on restaurant profitability during busy periods.

\footnotetext{
${ }^{24}$ S.E. Kimes, "Group Forecasting Accuracy for Hotels," Journal of the Operational Research Society, Vol. 50, No. 11, (1999), pp. 1104-1110.

${ }^{25}$ Kimes (2003), op. cit.

${ }^{26}$ S.E. Kimes and G.M. Thompson, "Restaurant Revenue Management at Chevys: Determining the Best Table Mix," submitted to Decision Science, 2003.

${ }^{27}$ S.E. Kimes and G.M. Thompson, "An Evaluation of Heuristic Methods for Determining the Best Table Mix in Full-Service Restaurants," submitted to Journal of Operations Management, 2003.

${ }^{28}$ Kimes et al. (1999), op. cit.; Kimes (2003), op.cit.
} 
If meal duration can be decreased, profit can increase, but the question becomes one of customer reaction to reductions in meal duration. In a pilot study in 2002, we found that meal duration could be reduced by nearly 20 percent without a decrease in customer satisfaction. ${ }^{29}$

\section{Areas for Future Research}

Revenue management lends itself to crossdisciplinary research. Although revenue management is inherently quantitative, its implementation involves serious issues arising from marketing, organizational behavior, human resources, and information technology. As mentioned above, revenue-management research can be divided into three categories: descriptive, pricing, and arrival and duration management. Potential areas of research in each category are discussed below.

\section{Descriptive Research}

Although revenue management has been applied to guest rooms and to a limited extent to golf courses, restaurants, and function space, a variety of other applications still exist. For example, could revenue management be applied to spas, to retail, to other recreational activities such as tennis? If so, what would it look like? How could revenue management be better applied to groups? How could hotels use revenue management to better control distribution channels?

\section{Pricing Research}

A variety of interesting research questions exist regarding pricing. For example, within the hotel industry, how could a hotel gain a better understanding of the price elasticity of its different market segments? How should hotels price their rooms in different distribution channels? How do customers react to the varying rates in different distribution channels? What impact do different rate-quoting strategies have on customers?

The application of revenue management to other industries opens up an entirely different

${ }^{29}$ S.E. Kimes, J. Wirtz, and B.M. Noone, "How Long Should Dinner Take? Measuring Expected Meal Duration for Restaurant Revenue Management," Journal of Revenue and Pricing Management, Vol. 1, No. 3 (2002), pp. 220-233.

\section{- Revenue Management - A Growing Stream of Research in Cornell Quarterly during the 1990s and Beyond}

Richard D. Hanks, Robert G. Cross, R. Paul Noland, "Discounting in the Hotel Industry: A New Approach," 33, 1 (February 1992), pp. 15-23.

Warren H. Lieberman, "Debunking the Myths of Yield Management," 34, 1 (February 1993), pp. 34-41.

Sheryl E. Kimes, "Perceived Fairness of Yield Management," 35, 1 (February 1994), pp. 22-29.

Sheryl E. Kimes and Douglas C. Lord, "Wholesalers and Caribbean Resort Hotels," 35, 5 (October 1994), pp. 70-75.

Laurence R. Weatherford, "Length-of-Stay Heuristics: Do They Really Make a Difference?," 36, 6 (December 1995), pp. 70-79.

Robert G. Cross, "Launching the Revenue Rocket: How Revenue Management Can Work for Your Business," 38, 2 (April 1997), pp. 32-43.

Ellis D. Norman and J. Mayer, "Yield Management in Las Vegas Casino Hotels," 38, 5 (October 1997), pp. 28-33.

Sheryl E. Kimes, Richard B. Chase, Sunmee Choi, Philip Y. Lee, and Elizabeth N. Ngonzi, "Restaurant Revenue Management: Applying Yield Management to the Restaurant Industry," 39, 3 (June 1998), pp. 32-39.

Eric B. Orkin, "Wishful Thinking and Rocket Science: The Essential Matter of Calculating Unconstrained Demand for Revenue Management, 39, 4 (August 1998), pp. 15-19.

Bill Quain, Michael Sansbury, and Stephen A. LeBruto, "Revenue Enhancement, Part 1: A Straightforward Approach for Making More Money," 39, 5 (October 1998), pp. $41-48$.

William (Bill) Quain, Michael Sansbury, and Ted Abernethy, "Revenue Enhancement, Part 2: Making More Money at Your Hotel," 39, 6 (December 1998), pp. 71-79.

William J. Quain, Michael Sansbury, and Dennis Quinn, "Revenue Enhancement, Part 3: Picking Low-hanging Fruit-A Simple Approach to Yield Management," 40, 2 (April 1999), pp. 76-83.

Sheryl E. Kimes, "Implementing Restaurant Revenue Management: A Five-step Approach," 40, 3 (June 1999), pp. 16-21.

Brian Sill and Robert Decker, "Applying Capacity-management Science: The Case of Browns Restaurants," 40, 3 (June 1999),pp. 22-30.

Bill Quain, Michael W. Sansbury, and Stephen M. LeBruto, "Revenue Enhancement, Part 4: Increasing Restaurant Profitability," 40, 3 (June 1999), pp. 38-41.

Sheryl E. Kimes, Deborah I. Barrash, and John E. Alexander, "Developing a Restaurant Revenue-management Strategy," 40, 5 (October 1999), pp. 18-29.

Sheryl E. Kimes, "Revenue Management on the Links: Applying Yield Management to the Golf-course Industry," 41, 1 (February 2000), pp. 120-127.

Sheryl E. Kimes and Paul Wagner, "Preserving Your Revenue-management System as a Trade Secret," 42, 5 (October 2001), pp. 8-15.

Sheryl E. Kimes and Jochen Wirtz, "Perceived Fairness of Demand-based Pricing for Restaurants," 43, 1 (February 2002), pp. 31-37.

Sunmee Choi and Sheryl E. Kimes, "Electronic Distribution Channels' Effect on Hotel Revenue Management," 43, 3 (June 2002), pp. 23-31. 
set of questions. How should an industry develop an optimal pricing strategy? How should it communicate this to its customers? What sorts of rate fences are the most effective? How will customers react to demand-based pricing in that industry?

\section{Duration Research}

Although a fair amount of research has been conducted on forecasting and overbooking for transient guest rooms, little research has been published on forecasting and overbooking for groups, for function space, or for restaurants. Initial research has been published on the optimal supply mix in restaurants, but what about the optimal supply mix for function space or for guest rooms?

Length-of-stay controls are commonly used for transient-guest rooms, but how could duration be better managed for groups, for function space, or for restaurants? How would customers react to such controls?

\section{Other Research}

The above list of questions and topics is by no means exhaustive. Another interesting area is total-hotel revenue management. With total- hotel revenue management, the objective is to maximize total revenue from all sources, not just from guest rooms. What would such a system look like? How would it work?

\section{Summary and Conclusion}

In this paper, I have reviewed the evolution of my research in revenue management and discussed areas for future research. I find revenue management particularly fascinating because of its multifaceted nature. Although many people associate revenue management with quantitative techniques such as forecasting, optimization, and overbooking, this only paints part of the revenuemanagement picture. Mere possession of a revenue-management system does not guarantee success. For a company to be successful with revenue management, it must have a clear understanding of the needs and price sensitivity of its various market segments, it must be able to fully integrate its revenue management system with other computerized systems, it must be able to properly train and motivate its employees and managers, and it must be able to quickly respond to competitive pressures from other hotels and from different distribution channels.

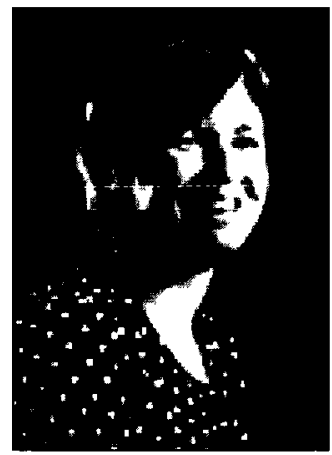

Sheryl E. Kimes, Ph.D. is a professor at the Cornell University School of Hotel Administration (sek6@cornell.edu). 